\title{
Re-print-Opioid Oligopoly and the Seven Deadly Sins (007)
}

\section{Robert G Smith DPM}

\author{
Shoe String Podiatry Ormond Beach, Florida, North America, USA
}

Corresponding author: Smith RG, Shoe String Podiatry Ormond Beach, Florida, North America, USA.

Received date: August 06, 2020; Accepted date: August 17, 2020; Published date: August 19, 2020

Citation: Smith RG, (2020). Opioid Oligopoly and the Seven Deadly Sins (007): J Clinical Research Notes, 1(3); DOI: 10.31579/2690-8816/026

Copyright: (C) 2020 Robert G Smith. This is an open access article distributed under the Creative Commons Attribution License, which permits unrestricted use, distribution, and reproduction in any medium, provided the original work is properly cited.

\section{Introduction}

An oligopoly is defined as a market structure with a small number of firms that dominate an industry, of which none can keep the other from significantly influencing the market.1 this market structure is distinctly different from other market forms. In today's market, the oligopoly structure is the most common market structure. It can be argued that the few pharmaceutical companies who market, manufacture, and distribute opioids all over the world constitute "opioid oligopoly." Bachtell has reported that dozens of opioid manufacturers, distributors, pharmacies, and doctors turn a blind eye to the opioid crisis swamping the United States.2

The opioid epidemic is considered to have occurred in three waves. The first wave began in 1991when deaths involving opioids began to sharply rise with an increase in the prescription of opioids or opioid-combination medications for treating pain. This increase was influenced by reassurances from pharmaceutical companies and medical societies or associations, emphasizing the low risk of addiction from using such medications. The second wave of the epidemic started around 2010 when the number of deaths from heroin abuse rapidly increased. Around this time, the early efforts of both state and federal regulators to decrease the prescription of opioid-based medicines began to take effect, making obtaining opioids harder. As a result, opioid users turned to heroin, which is cheaper, more widely available (albeit illegally), and extremely potent. The third wave of the epidemic began around 2013 as deaths related to synthetic opioids such as fentanyl started to increase. However, the most significant rise in opioid-related deaths occurred in 2016; over 20,000 people died from abusing fentanyl and other related drugs. The current consensus is that numerous parties are responsible for the present-day opioid epidemic.3, 4 the opioid-related death rates of nearly two decades has significantly increased and out-paced the short-term data regularly cited by policymakers while assessing the epidemic and the effectiveness of the opioid crisis public health response.5, 6

The seven deadly sins are human character vices and original sins that date back to early Christian times. Human behaviors or habits can be considered sinful if they directly give birth to other immoralities. Generally, the seven deadly sins are pride, greed, envy, lust, gluttony, sloth, and wrath. These sins are often thought to be abuses or excessive versions of humans' natural faculties or passions. The main purpose of this narrative is to use and apply each of the seven deadly sins to the opioid oligopoly to illustrate the magnanimity of their contributions to the opioid crisis.
Pride. It is natural for owners to be proud of their businesses, but they should be proud as long as their company utilizes ethical practices. But a Question comes to mind: Should a physician, who has a private practice or owns a drug company, apply the principle of "primum non nocere," which is Latin for "first, do no harm"? Physicians may be influenced by their or other pharmaceutical sales representatives to prescribe a product to promote and market it. Kornfield et al. Published a review7 regarding the promotion of prescription drugs to consumers and providers between 2001 and 2010. They concluded that during this period, branded pharmaceuticals, including Oxycontin $\AA$, expended a considerable amount of money on promotion to influence consumers as well as providers.7 Schwartz and Woloshin8 published a data-centered study on medical marketing in the United States during 1997-2016. They found that during this period, the expenditure on medical marketing of drugs, disease awareness campaigns, health services, and laboratory testing increased from $\$ 17.7$ to $\$ 29.9$ billion.7 Van Zee used the "Oxycontin ${ }^{\circledR}$ Marketing Plans from 1996-2001" to make a valid argument that the manufacturers of OxyContin ${ }^{\circledR}$ pursued an "aggressive" marketing campaign to promote the use of opioids by emphasizing the greater benefits of choosing opioid-based products over other products without disclosing the involved risks.9 Perhaps, if the opioid oligopoly had tempered their pride with a little humility, they might not have been so aggressive with the promotion and marketing of their opioid-based products and might have realized the harm that they were inflicting and would have organized a mitigating campaign directed at the opioid crisis.

Hoffman has offered a commentary centered on the concept of "privilege vs. right" in the healthcare system and defended the position that this dichotomy is a failed binary, as it has divided the nation.10 the "right" claim strives to redefine the influence of authority in the healthcare system. The efforts to make the right to healthcare into legislation failed because no such right has been either explicitly or implicitly enumerated in the constitution.10 Further, Hoffman asserts that the "privilege" end of the healthcare system has been damaging, shifting the burden away from the physician to the patient.11 It is medicine's historic privilege to care for any human being, but the obligation has become obscure due to the opportunistic actions of opioid oligopoly. 11 Hoffman concludes that both large companies and influential politics in healthcare have become ends unto themselves, and therefore, neither can answer the privilege question nor bear the weight of enforcing physicians' obligation to give healthcare to patients. 11

Greed. It is, of course, natural for any pharmaceutical company to want to make a profit. A company creates jobs and enhances the local-, state-, 
and national-level economic development. The opioid oligopoly has made a substantial amount of profit from aggressively and successfully marketing its products. This is completely understandable, but then again, it should be acknowledged that opioid oligopoly should have proceeded more prudently. Ellenbogen and Segal published their findings in a report where they examined the differences in the prescription of opioids among general physicians, nurses, and physician assistants. 12 They conducted a serial cross-sectional analysis of the data regarding the prescription claims during 2013-2016, which was collected from the public domain of the Centers for Medicare and Medicaid Services.12 The analysis showed relatively higher rates of opioid prescriptions among nurses and physician assistants.12 A factor contributing to this high rate of opioid prescription by midlevel healthcare professional may be understood by a piece of recent news, which reports that Purdue Pharma told pharmaceutical representatives "that midlevel providers are critical to our success" and referred to them as "high-value Oxycontin ${ }^{\circledR}$ prescribers" in a 2015-2016 training session.13 From all these, a valid argument can be made that opioid oligopoly got so caught up in attaining greater profits that it forgot to abide by the most important aspect of healthcare-the ethical responsibility to do no harm and to stand as a community leader.

Envy. It can be considered natural for a company to fall into the temptation of envy when it covets its competitor's business model. Envy wanes the spirit of fair play, and consequently, a company procures the resentment of other businesses of the opioid oligopoly that could have possibly acted as allies to mitigate the opioid crisis fueled by them. Nguyen et al. analyzed Medicare part D prescription data from 2014 to 2016 to study how pharmaceutical payments influence physicians.14 They discovered that prescribers who received opioid-specific payments during that period prescribed 8,784 daily opioid doses per year, which is much more than their peers who did not receive such payments. Such payments resulted in 5,161 additional daily doses of hydrocodone, 3,624 additional daily doses of oxycodone, and 1,124 daily doses of fentanyl, which are more than those prescribed by the physicians who did not receive any incentives from pharmaceutical companies.14 Among the 63,062 physicians who received such payments, a $1 \%$ increase in the number of payments resulted in 50 daily opioid doses. 14 These authors concluded that physicians who receive direct payments from opioid companies are motivated to prescribe substantially larger quantities of opioid-based medications, particularly hydrocodone and oxycodone.14 The opioid oligopoly offering incentive payments to prescribers of opioids through their agents to calm their envy is a spurious behavior, especially since opioids eventually cause patients harm. Mundipharma and Purdue Pharma are specialized global pharmaceutical companies that are owned by a family who cites statistics to suggest there is a significant unmet need for their opioid products. All clinicians all over the world should consider all the information provided by companies that promote and sell their products as a means to satisfy their greed and tamper down their own envy toward other opioid companies of the oligopoly.

Lust. Lust can be envisioned as a kind of envy but on anabolic steroids. For this argument, "lust" will be defined as the profits garnered by the opioid oligopoly from selling their products.

Purdue Pharma has denied the allegations accusing them of contributing to the opioid crisis and averred that heroin and fentanyl are more responsible than opioid painkillers and that the United States Food and Drug Administration (FDA) approved labels that bared warnings about the risks of using opioid.15, 16 It must be addressed that Purdue Pharma has faced around 2,000 lawsuits over the promotion and advertisement of their product Oxycotin ${ }^{\circledR} 16$ over the last few years.
Marketing to physicians is not the only strategy employed by the opioid oligopoly. Between 2012 and 2017, five opioid manufacturers gave nearly $\$ 9$ million to 14 patient advocacy groups and medical societies. Although the amount is a mere drop in an ocean of the billions of dollars in opioid revenues garnered by drug companies, the incentives were substantial for the recipients. As a result of the payments, many of them issued guidelines that minimized the caution regarding the addiction risks of prescription opioids. They also extensively lobbied to defeat legislation restricting opioid prescriptions. When the Centers for Disease Control and Prevention (CDC) issued its 2016 draft guidelines to limit opioid use, the majority of the opposition constituted organizations that received industry funding.15 Purdue Pharma documents revealed that the company knew that their opioid-based products would cause addiction and that they should consider getting into the business of selling drugs that treat addiction.15,16 The leaders of the company wrote internal documents that suggested that opioids and addiction are naturally linked and Purdue Pharma should consider becoming an "end-to-end pain provider," providing opioids to addicts to treat pain and then offering suboxone to treat addiction. 16 Purdue Pharma proposed "Project Tango," according to which their team mapped out how patients could get addicted to prescription opioid analgesics such as OxyContin ${ }^{\circledR}$ or heroin, and then, those addicts would become the consumers of the new company's suboxone.16 Imagine a world where the new normal is a clinician prescribing opioids and where he is also having to prescribe a drug for opioid overdose, such as naloxone, as a standard of care. Are these prescription fees or dispensing prices automatically paid by the opioid oligopoly? The answer is "NO." The cost is incurred by the patient or the taxpayer. Further, Insys Therapeutics' drug Subsys ${ }^{\circledR}$, which is 100 times stronger than morphine, was approved by the Food and Drug Administration (FDA) to treat patients with cancer who had a "breakthrough" pain that could not be addressed by other medicines. In October 2017, a group of executives of Insys Therapeutics was charged with multiple conspiracies, including racketeering, kickbacks, and fraud, along with two other former executives who pleaded guilty and became cooperating witnesses, as their only goal was to pursue profit. Lastly, Purdue Pharma documents reported a large increase in opioid addiction over the last five years, further noting that opioid addiction can happen to anyone and then suggesting that the market for drugs to treat addiction would be profitable since there is a large unmet need for treating the vulnerable, underserved, and stigmatized patient population suffering from substance abuse, dependence, and addiction. 16

For a better understanding of how "lust" influences the desire for garnering profits of the opioid oligopoly, a parallel must be established between the opioid oligopoly and illicit drug dealers. Jacques et al. found that drug dealers typically exploit six types of customers: persons who are uninformed about drugs, first-time or irregular customers, persons who do not have sufficient money on hand to buy drugs, persons who are uninformed about the current market rates, persons who are deemed unlikely to retaliate, persons who are offensive, and persons who are addicted to drugs.17 Dealers target these groups since they perceive them as unlikely repeat customers, not worth the hassle of doing business with, unlikely to realize that they are being ripped off, being in the wrong and thus deserving of payback, and someone unwilling to retaliate or take their money elsewhere.17 The opioid oligopoly views consumers as nameless strangers, first-time or irregular customers who will crave their opioids for decades and do anything to buy them. Further, Tzvetkova et al. have described the strategies used by drug dealers to manage their customers. 18 their investigation revealed that illicit drug dealers engaged in repeated transactions and their relationships with their customers were 
based on trust and reputation similar to the opioid oligopoly. Illicit drug dealers as well as the opioid oligopoly aimed to sell good-quality drugs to their regular customers who might have become addicted.18 Drug dealers sought to maximize their profits by decreasing the quality of their drugs by mixing them with cutting agents. The quality of the drugs could affect their reputation and thus their profits and position in the market. Given that the opioid oligopoly cannot alter their products, they relied on paying prescribers, targeting clinicians who treat at-risk populations, and misleading providers and regulatory agents to boost opioid sales and increase opioid dependency for satisfying their lust for profit.

Gluttony. The inference can be easily understood that as a business owner, one is supposed to harbor the desire to make as much money as possible. However, to fulfill this desire, the opioid oligopoly builds their business models based on deceit and deception without accounting for the harm they might cause to consumers. They make their profits at the expense of society and have been credited to be the cause of the first wave of the opioid crisis. It should be emphasized yet again that the first wave began in 1991 with a sharp rise in the number of deaths caused by prescription opioids and opioid-combination medicines to treat pain.19,20 It has been seen that this increase was influenced by reassurances from pharmaceutical companies and medical societies or associations that emphasized that the risk of addiction to prescription opioids is very low.19,20 Most of the available interventions proposed by state and national regulators to limit the prescription of opioids and its abuse failed due to the force of the culture emerging from the confluence of interests of the opioid oligopoly that curry favor with influential academics and pain societies.20 To fulfill their all-consuming hunger for profit and prestige, the opioid oligopoly exerted a profound influence on the medical culture causing a paradigm shift toward the over-prescription of opioid products. From the opioid oligopoly's behavior, it can be understood that ethically conducting business and leaving a fair share for other companies was completely ignored.

Sloth. This sin is the most difficult to define. It is also hard to credit it as a sin since it involves a peculiar jumble of notions, dating from antiquity and including mental, spiritual, pathological, and physical states. For making this argument, sloth will be defined as spiritual apathy. One of the best examples of spiritual apathy showcased by opioid oligopoly can be seen in their documents, which state that these companies knew that their opioid-based products would cause addiction and that they should consider getting into the business of selling drugs to treat addiction caused by their products.15, 16 This allows concluding that the opioid oligopoly can profit on both sides by fueling the opioid crisis. A company wrote in its internal documents that opioids and addiction are naturally linked and that it should consider becoming an "end-to-end pain provider," providing opioids to control pain and then offering suboxone to treat addiction.15,16 Van Zee's credible argument9 centered on an aggressive marketing campaign for OxyContin ${ }^{\circledR}$ to promote the use of opioids by emphasizing its greater benefits compared to other products without disclosing the risks, which demonstrates the manufacturer's spiritual apathy toward patients and providers. The website OpenSecrets.org reported that a member of the opioid oligopoly lobbyist spent $\$ 470,000$ in 2011, $\$ 710,000$ in 2012, $\$ 740,000$ in $2013, \$ 810,000$ in $2014, \$ 720,000$ in 2015 , $\$ 714,000$ in $2016, \$ 940,000$ in $2017, \$ 1,120,000$ in 2018 , and $\$ 800,000$ in 2019 to protect and boost their opioid sales. Lastly, a group of opioid oligopoly executives from another opioid producer being charged with multiple conspiracies is an excellent example of the opioid oligopoly's spiritual apathy as well as moral bankruptcy toward humankind.
Wrath. Wrath may be defined as intense vengeful anger, indignation, or retributory punishment for an offense or crime. In the absence of a divine disciplinary regulatory, a great number of plaintiffs within the United States have filed thousands of lawsuits against pharmacies, drug manufacturers, drug distributors, and physicians for their alleged roles in fueling the opioid epidemic. It has been understood that opioid prescription therapy can be associated with substantial known risks. The increase in the number of deaths from prescription opioid overdose deaths has increasingly led to the clinician liability and sanctions.22 While liability can deter the providers from recklessly prescribing opioids, it may also discourage well-intentioned prescribers and compromise patient pain management.22 Medical malpractice lawsuits is the most conventional form of liability that the providers face for any patient injury resulting from the prescribed opioids. 22 The widely available opioidprescribing guidelines can now help courts determine what a reasonable, prudent physician would have done in the same situation.22 Opioid prescribers can be criminally charged under the federal Controlled Substances Act and its state equivalents.23,24 Under this federal law, the Drug Enforcement Administration (DEA) increasingly prosecutes physicians who knowingly and intentionally prescribe drugs outside the usual course of medical practice or for non-legitimate medical purposes. 23

Across the United States, various plaintiffs have filed thousands of lawsuits against pharmacies, drug manufacturers, drug distributors, and physicians for their alleged roles in fueling the opioid epidemic. These lawsuits can be related to three areas: (1) A group of more than 2,000 lawsuits filed against the pharmaceutical supply chains and individual physicians by counties, cities, Native-American tribes, and individuals across the United States is referred to as the "National Prescription Opiate Litigation"; (2) The cases brought by two counties in Ohio against certain pharmaceutical supply chain, which are referred to as the "Ohio case"; (3) Individual state lawsuits brought by 48 state attorney generals against Purdue Pharma and other drug companies. 25

The class-action suit that shows the causal relationship between companies' business practices and the harm they cause to consumers is assessed at a group level, with the focus on establishing statistical associations between product use and injury. Nevertheless, early attempts to bring class-action suits against opioid manufacturers encountered procedural barriers. Due to the varying factual circumstances surrounding individuals' opioid use and clinical conditions, judges often deemed the proposed class members to lack substantial common claims.26 As a defense maneuver, Purdue Pharma requested the counties suing them to validate their claims; their request was upheld by the presiding judges.26 Mandatory reporting was required by manufacturers, distributors, or importers. Attorney General Maura Healey's lawsuit against Purdue Pharma claimed that the company contributed to the opiate explosion. The company allegedly denied and downplayed the addictive potential of its opioid-based products. It was suspected that patients received discounts on purchasing the drugs for the first time, increasing the likelihood that they would stay on the drugs for a longer period of time. Furthermore, it was claimed that the company pressured doctors into prescribing OxyContin ${ }^{\circledR}$ more often, in higher doses, and for longer periods by lavishing them with gifts and money. Settlements were reached with drug distributors, drug makers, and other companies, and they were in the range of \$260 million with AmerisourceBergen, Cardinal Health, McKesson, and Teva Pharmaceuticals to just over a $\$ 1$ million settlement with the small drug distributor Henry Schein Medical in an Ohio case.25 The settlements will be used to reimburse the counties for legal fees and other 
expenses related to the opioid epidemic, fund local nonprofits and foundations with opioid-related programs, and provide generic products to the counties, including medications used to treat opioid-related substance abuse. 25 A $\$ 48$ billion agreement settled the lawsuits filed by the attorney generals in North Carolina, Pennsylvania, Tennessee, and Texas localities against five companies: AmerisourceBergen, Cardinal Health, Johnson \& Johnson (J\&J), McKesson, and Teva. Under the agreement, the companies would pay a total of $\$ 22$ billion in cash and contribute $\$ 26$ billion worth of generic treatments for substance abuse, product distributions, and data-tracking measures. 25

Opioid multidistrict litigation: National Prescription Opiate Litigation (MDL 2804). This national opioid litigation was initially transferred to Cleveland in 2017, and the first bellwether trial was planned to take place in October 2019. The case was settled hours before the trial even began. Judge Polster who presided over the case had set further bellwether tracks for several plaintiffs and defendants who filed lawsuits the next year. Some plaintiff attorneys advocated for a global negotiation to settle the cases of all the entities within the MDL.

Purdue bankruptcy: Purdue Pharma L.P. (Case no. 19-23649). Purdue's bankruptcy case was initiated in the southern district of New York on September 15, 2019. The case included Purdue Pharma L.P. and 23 other affiliated debtors who each filed a voluntary petition for relief under Chapter 11 of the United States Bankruptcy Code. The case was to be presided over by the Honorable Robert D. Drain. Through this bankruptcy case, Purdue hoped to halt all lawsuits against it by offering a settlement of \$10-12 billion. The Sackler who own Purdue Pharma L.P. family offered $\$ 3$ billion from their personal fortune. The company continued selling OxyContin ${ }^{\circledR}$ and other medicines with the profits used to pay the plaintiffs. It has offered to donated to addiction treatment and overdose reversal drugs, several of which are still in development.25

According to Mahatma Gandhi's teachings, curing each of the seven deadly sins is an explicit external standard or something that is based on natural principles and laws, not on social values. His teachings emphasize the abandonment of values that involve wealth without work, pleasure without conscience, knowledge without character, commerce without morality, science without humanity, religion without sacrifice, and politics without principles.27 As Gandhi pointed out, pride and selfishness will destroy the union between man and God, between man and woman, between man and man, between self and self; this is demonstrated by the behaviors by the opioid oligopoly.27 Perhaps, if the CEOs of opioid oligopoly were humble and servant leaders who sacrificed their pride and shared their power, they could have influenced the parties both inside and outside their oligopoly and potentially mitigated the opioid crisis in today's society. The opioid oligopoly applied science to its business model without humanity and achieved great riches without real human advancement. Fairness and benevolence in business are the foundation of a free enterprise system. 27 it should be remembered that every business transaction poses a moral challenge to ensure that both parties get their fair share.27 the opioid oligopoly conducted business without morality and thus took advantage of prescribers and victimized patients with opioid addiction. Finally, the opioid oligopoly obtained knowledge on opioid addiction and acted without character by promoting a business model to make profit by making their consumers addicted to opioids and treating opioid addiction of the same patient population.

\section{Conclusion}

The main purpose of this commentary is to apply each of the seven deadly sins to the actions of the businesses of opioid oligopoly to illustrate the magnitude of the influence their actions have on the opioid crisis. The title "Opioid Oligopoly and the Seven Deadly Sins (007)" emphasizes the fact that the opioid oligopoly by relying on, living, and applying the seven deadly sins to their business model allow themselves to hold a license to kill like Ian Fleming's James Bond. As a British literary and film character, a peerless spy, notorious womanizer, and masculine icon, Bond is a highly unique individual who appears to be of sound mind and strong spirit. However, unfortunately, the opioid oligopoly does not embrace these characteristics and was exceedingly cunning and diabolical and extremely sly in their actions and behaviors leading to the creation of a business model that fueled the opioid crisis.

\section{References}

1. (2020). Oligopoly Definition of Oligopoly by Merriam.

2. Bachtell J. (2020). Big pharma companies are the "drug kingpins" of the opioid crisis.

3. Jones MR, Viswanath O, Peck J, et al. (2018). A brief history of the opioid epidemic and strategies for pain medication. Pain Ther. 2018 Jun; 7(1): 13-21.

4. Ostling PS, Davidson KS, Anyma BO, et al. (2018).America's opioid epidemic: A comprehensive review and look into the rising crisis. Curr Pain Headache Rep. 2018 Apr; 22(5): 32.

5. (2017).National Academies of Sciences, Engineering, and Medicine; Health and Medicine Division; Board on Health Sciences Policy, et al. Pain management and the opioid epidemic: Balancing societal and individual benefits and risks of prescription opioid use. Washington, DC: National Academies Press.

6. VanHouten JP, Rudd RA, Ballesteros MF, Mack KA. (2019).Drug overdose deaths among women aged 30-64 yearsUnited States, MMWR Morb Mortal Wkly Rep.; 68:1-5.

7. Kornfield R, Donohue J, Berndt ER, Alexander CG. (2013). Promotion of prescription drugs to consumers and providers, PLoS One.8: e55504.

8. Schwartz LM, Woloshin S. (2019).Medical marketing in the United States, 1997-2016. JAMA. 2019; 321: 80-96.

9. Zee AV. (2009). The promotion and marketing of oxycontin: Commercial triumph, public health tragedy. Am J Public Health. 99: 221-227.

10. Hoffman WW. (2019). The patient as obligation - The binary failure of "privilege" vs. "right" part 1 - My right - Sez who? S D Med. 72(12): 562-571.

11. Hoffman WW. (2020). The patient as obligation - The binary failure of "privilege" vs. "right" part 2 - My privilege - From the great equation to an American sickness to mac and cheese for all to an American idea. S D Med. 73(1): 22-31.

12. Ellenbogen MI, Segal JB. (2019).Differences in opioid prescribing among generalist physicians, nurse practitioners, and physician assistants. Pain Med. pii: pnz005.

13. Nelson KL. (2018). Purdue targeted nurse practitioners, PAs, but doctors had to sign off on all prescriptions. Knoxville News Sentinel.

14. Nguyen TD, Bradford WD, Simon KI (2019) Pharmaceutical payments to physicians may increase prescribing for opioids. Addiction.114: 1051-1059.

15. Marks JH. (2019). Opioid crisis shows partnering with industry can be bad for public health. 
16. (2019). Schoenberg S. Purdue Pharma's secret plan to profit off opioid addiction outlined in court filing.

17. Jacques S, Allen A, Wright R. (2014). Drug dealers' rational choices on which customers to rip-off. Int J Drug Policy. 2014; 25(2): 251-256.

18. Tzvetkova M, Pardal M, Disley E, Rena A, Talic S, et al. (2016). Strategies for a risky business: How drug dealers manage customers, suppliers and competitors in Italy, Slovenia and Germany. Int J Drug Policy. 2016; 31:90-98.

19. Smith RG. (2018). The non-symmetric axiom $x x \neq x y$ of the opioid crisis. Adv Res Foot Ankle. 2018; 1: 115.

20. Smith RG. (2018). Using clinical-based evidence as the sextant to prescribe and navigate through the opioid crisis. Foot and Ankle Quarterly. 29: 143-208.

21. (2020). Open Secrets Org, Center for Responsive Politics Purdue Pharma Lobbying.
22. ang YT, Larochelle MR, Haffajee RL. (2016). Managing increasing liability risks related to opioid prescribing. 130(3): 249-250. doi:10.1016/j.amjmed.2016.08.041.

23. Barnes M.C., Sklaver S.L. (2013).Active verification and vigilance: A method to avoid civil and criminal liability when prescribing controlled substances. DePaul J Health Care Law. 2013; 15: 93-145.

24. (1988). Title 21 United States Code (USC) Controlled Substances Act. 21 U.S.C. $\$ 801$ et seq.

25. Antonelli AF. (2019). Overwhelmed by all the multi-milliondollar opioid settlements? Here's everything youneed to know.

26. Haffajee RL, Mello MM. (2017). Drug companies' liability for the opioid epidemic. N Engl J Med. 2017; 377: 2301-2305.

27. (2020). Stephen RC. Mahatma Gandhi: Seven deadly sins excerpts from Chapter 7 - Seven deadly sins. Principle-centered leadership. 87-93.
This work is licensed under Creative Commons Attribution 4.0 License

To Submit Your Article Click Here: Submit Article

DOI: $10.31579 / 2690-8816 / 026$
Ready to submit your research? Choose Auctores and benefit from:

* fast, convenient online submission

* rigorous peer review by experienced research in your field

* rapid publication on acceptance

* authors retain copyrights

* unique DOI for all articles

* immediate, unrestricted online access

At Auctores, research is always in progress.

Learn more www.auctoresonline.org/journals/clinical-research-notes- 